\title{
Saccharomyces cerevisiae in the respiratory system, digestive system and on the skin in humans
}

\author{
MARIA DYNOWSKA, MAŁGORZATA ROSŁAN ${ }^{1}$ and KATARZYNA GÓRALSKA
}

\author{
Department of Mycology, University of Warmia and Mazury in Olsztyn \\ Oczapowskiego 1A, PL 10957 Olsztyn, dynow@uwm.edu.pl \\ ${ }^{1}$ Laboratory of Bacteriology of Independent Public Centre for Tuberculosis and Lung Diseases \\ Jagiellońska 78, PL 10357 Olsztyn
}

Dynowska M., Rosłan M., Góralska K.: Saccharomyces cerevisiae in the respiratory system, digestive system and on the skin in humans. Acta Mycol. 41(1): 139 144, 2006.

The results of observations on the occurrence of $S$. cerevisiae in the respiratory and digestive systems and on the skin in hospitalised individuals, mostly belonging to so called risk groups of fungal infections, conducted over a period of five years (1999 2004), are described and discussed. The participation of $S$. cerevisiae in the mycocoenoses studied was $11.04 \%$ of all the recorded fungi. A significant increase in its prevalence, especially on the skin, was noticed. The fungus was mostly isolated with fungi of the genera Candida and Trichosporon, as well as separately in the last two years of the study.

Key words: $S$. cerevisiae, ontocoenoses, prevalence

\section{INTRODUCTION}

True yeasts of the genus Saccharomyces are some of the numerous fungi that may colonise the oral cavity and the digestive tract in humans commensally and asymptomatically (Kurnatowska 1995). S. cerevisiae, one of the many species of this genus, is mostly associated with fermentation processes or the production of some vitamins $\left(\mathrm{B}_{1}, \mathrm{~B}_{2}, \mathrm{PP}\right.$, pantothenic acid) and less frequently with pathogenic processes. Biologists know that yeasts are an excellent object of study in cytology, enzymology, growth and development physiology, dimorphism and genetics (Dy nows k 1995). Relatively little, however, is known about yeasts as causal agents of mycoses despite an increasing number of reports from medical mycologists on the expanding range of aetiological factors of diseases caused by yeasts (Dynowska, Bie dunkiewicz 2001). Only few list $S$. cerevisiae as a potential anthropopathogen belonging to opportunistic fungi.

Long-term observations on human-related fungi, both in healthy and compromised individuals, based on routine mycological diagnostics using clinical material, show that the occurrence frequency of $S$. cerevisiae in various human ontocoenoses 
deserves attention (Dynowska, Ejdys, Kisick a 2004). Therefore, its occurrence in positive mycological results of the Laboratory of Bacteriology at the Independent Public Centre for Tuberculosis and Lung Diseases, Olsztyn, was analysed over a period of five years.

\section{MATERIAL AND METHODS}

Smears from various body sites, including bedsores and post-operative wounds, smears from the oral cavity, throat, large intestine and anus as well as sputum and bronchoscopic fluid constituted the study material.

Fungi were incubated according to general guidelines recommended for diagnostic laboratories: macrocultures - Sabouraud agar, microcultures - Nickerson agar, incubation at $37^{\circ} \mathrm{C}$ for $48-72$ hours (Kurnatowsk a 1995; Pawlik, Macura 1998).

A total of 2880 samples in which any fungi were recorded were examined over a period of five years (1999-2004). Samples were collected from 1420 men and 1 460 women who constituted a group of oncological patients and patients suffering from respiratory system disorders, including suspected tuberculosis. Yeasts mostly accompanied numerous yeast-like fungi. Samples containing $S$. cerevisiae were additionally tested in Sabouraud broth (microscopic sediment analysis) and fermentation and sugar assimilation abilities were assessed. The production of asci and pseudohyphae was observed on Gorodkow agar and a cornmeal substrate, respectively (Kurnat owska 1995). Fungi were determined using the following keys: Barnett, Payne and Yarrow (1990) and Kreger-van Rij (1984).

\section{RESULTS}

A total of 318 isolates of S. cerevisiae, 145 in men and 173 in women, were obtained from the patients' respiratory and digestive systems and skin, which constitutes $11.04 \%$ of all recorded fungi (Tab. 1). Yeasts accompanied fungi of the genera Candida and Trichosporon in the vast majority of cases. S. cerevisiae was observed separately in the last two years of the study (2003 and 2004). In these cases, growth was abundant, and the entire field of vision in direct microscopic slides was covered by vegetative cells and intensively budding cells.

The digestive system, followed by the respiratory system, was the ontocoenosis colonised by $S$. cerevisiae most often. The fungus was recorded on the skin very rarely between 1999 and 2002, and its frequency was comparable to that in other ontocoenoses between 2003 and 2004. While yeasts occurred in the respiratory and digestive systems in men and women with a similar frequency (with a slight shift towards women), they were recorded almost twice as often on the skin in women (Tab. 1). They were usually isolated in summer and autumn, and rarely in spring and winter. A significant increase in the prevalence of the species studied was observed in the study period and it went from $1.90 \%$ in 1999 to $3.53 \%$ in 2005 . 
Saccharomyces cerevisiae in the respiratory

Table 1

Number of $S$. cerevisiae isolates in the study material in women (W) and men (M) in different seasons of the year (1999 2004)

\begin{tabular}{|c|c|c|c|c|c|c|c|c|c|c|c|}
\hline \multirow[t]{3}{*}{ Year } & \multirow[t]{3}{*}{ Season } & \multicolumn{6}{|c|}{ Ontocoenosis } & \multicolumn{2}{|c|}{ Total } & \multirow[t]{3}{*}{ Total } & \multirow{3}{*}{$\begin{array}{l}\%(\text { in relation to } \\
\text { the total number, i.e } \\
2880)\end{array}$} \\
\hline & & \multicolumn{2}{|c|}{$\begin{array}{l}\text { respiratory } \\
\text { system }\end{array}$} & \multicolumn{2}{|c|}{$\begin{array}{l}\text { digestive } \\
\text { system }\end{array}$} & \multicolumn{2}{|c|}{ skin } & & & & \\
\hline & & $\mathrm{W}$ & M & $\mathrm{W}$ & $\mathrm{M}$ & $\mathrm{W}$ & M & $\mathrm{W}$ & M & & \\
\hline \multirow[t]{3}{*}{$1999 / 2000$} & $\mathrm{Sp}$ & 1 & & 3 & 2 & 2 & & 6 & 2 & 45 & 1.90 \\
\hline & $\mathrm{Su}$ & 2 & 1 & 6 & 4 & 4 & 2 & 12 & 7 & & \\
\hline & A & 1 & 1 & 6 & 4 & 1 & 1 & 8 & 6 & & \\
\hline \multirow[t]{4}{*}{$2000 / 2001$} & $\mathrm{~W}$ & 1 & & 2 & 1 & & & 3 & 1 & \multirow[t]{4}{*}{37} & \multirow[t]{4}{*}{1.21} \\
\hline & $\mathrm{Sp}$ & 2 & 1 & 2 & 2 & & & 4 & 3 & & \\
\hline & $\mathrm{Su}$ & 3 & 2 & 4 & 2 & 2 & 2 & 9 & 6 & & \\
\hline & A & 3 & 2 & 3 & 1 & 1 & 1 & 7 & 4 & & \\
\hline \multirow[t]{4}{*}{$2001 / 2002$} & W & 1 & & 1 & 1 & 1 & & 3 & 1 & \multirow[t]{4}{*}{60} & \multirow[t]{4}{*}{2.08} \\
\hline & $\mathrm{Sp}$ & 2 & 1 & 4 & 3 & 2 & & 8 & 4 & & \\
\hline & $\mathrm{Su}$ & 5 & 3 & 8 & 5 & 1 & & 14 & 8 & & \\
\hline & A & 3 & 2 & 7 & 5 & 2 & & 12 & 7 & & \\
\hline \multirow[t]{4}{*}{$2002 / 2003$} & W & 1 & 1 & 2 & 2 & 1 & & 4 & 3 & \multirow[t]{4}{*}{74} & \multirow[t]{4}{*}{2.22} \\
\hline & $\mathrm{Sp}$ & 2 & 2 & 3 & 3 & 2 & & 7 & 5 & & \\
\hline & $\mathrm{Su}$ & 4 & $6(2)$ & 5 & $6(2)$ & $4(1)$ & $4(1)$ & 13 & 16 & & \\
\hline & A & $4(2)$ & $4(2)$ & $5(2)$ & $6(3)$ & $4(1)$ & $3(1)$ & 13 & 13 & & \\
\hline \multirow[t]{5}{*}{$2003 / 2004$} & W & 2 & 1 & 2 & 2 & & & 4 & 3 & \multirow[t]{5}{*}{102} & \multirow[t]{5}{*}{3.53} \\
\hline & $\mathrm{Sp}$ & 2 & 4 & 3 & 3 & $3(1)$ & 1 & 8 & 8 & & \\
\hline & $\mathrm{Su}$ & $8(3)$ & $10(2)$ & $6(2)$ & $6(2)$ & $4(2)$ & $4(2)$ & 18 & 20 & & \\
\hline & A & $8(2)$ & $10(2)$ & 3 & $6(1)$ & $4(2)$ & $4(2)$ & 15 & 20 & & \\
\hline & W & $2(2)$ & $5(2)$ & 1 & $2(1)$ & 2 & 1 & 5 & 8 & & \\
\hline \multirow{2}{*}{\multicolumn{2}{|c|}{ Total }} & 57 & 56 & 76 & 66 & 40 & 43 & 173 & 145 & 318 & 11.04 \\
\hline & & \multicolumn{2}{|c|}{113} & \multicolumn{2}{|c|}{142} & \multicolumn{2}{|c|}{63} & \multicolumn{2}{|c|}{318} & & \\
\hline \multicolumn{2}{|c|}{$\begin{array}{c}\% \text { (in relation to the } \\
\text { total number, i.e. } \\
2880)\end{array}$} & \multicolumn{2}{|c|}{3.89} & \multicolumn{2}{|c|}{4.97} & & & & & & \\
\hline
\end{tabular}

(1) number of S. cerevisiae isolates occurring separately; Sp spring, Su summer, A autumn, W winter 


\section{DISCUSSION}

S. cerevisiae is a typical representative of F. Saccharomycetaceae, O. Endomycetales which combines features of Zygomycetes and Ascomycetes. Dicaryophase, ascocarps and ascogenous hyphae are absent in yeasts, and asci are produced directly from the zygote. $S$. cerevisiae cells are characterised by a great size differentiation depending on the strain: $4.5-10.5 \times 7.0-21.0 \mu \mathrm{m} ; 3.5-8.0 \times 5.0-11.5(17.5) \mu \mathrm{m}$; $2.5-7.0 \times 11.0-18.5 \mu \mathrm{m}$. The diameter of single cells of some strains was up to $30 \mu \mathrm{m}$. The chemical composition and the organisation of the structure of the cell wall in yeasts diverge from those of most fungi. It consists of cell dry mass in 1920\%; polysaccharides (mostly glucans and mannans) constitute 80-90\% while chitin only ca. $10 \%$. The thallus of $S$. cerevisiae is small and reproduces by budding, leaving scars, with blastospores. It may be haploid or diploid in the vegetative stage. It may elongate into pseudohyphae, sometimes breaking down into blastospores, in microaerophilous conditions or when trophic conditions are disturbed. However, budding is mostly the only form of growth in $S$. cerevisiae: intensive multiplication and an increase in the number of vegetative cells take place as the biomass increases. It is of great significance for the rate of medium colonisation, including human tissue (Dynowska 1995).

Yeasts of two genera, Saccharomyces and Hansenula, have been isolated from the human body, and only Saccharomyces occurred asymptomatically. Apart from $S$. cerevisiae, $S$. italicus Casteli and $S$. rouxii Boutroux have been observed. They have mostly been recorded in the contents of the oral cavity and in faeces, less frequently in other biological material (Ku rn a tow sk a 1995). Both genera can cause systemic yeast infections. Saccharomycoses have been recorded in the oral cavity, stomach, intestines, reproductive organs, respiratory system (bronchi and lungs), in the external ear and on the skin. Hansenula infections have been recorded in the blood, central nervous system, endocardium and lymph nodes (Ku rnat ow ska 1995).

A relatively low percentage of $S$. cerevisiae in the study material should not divert attention from the species' pathogenic abilities, especially because the number of its records has been growing and the fungus is beginning to occur on its own. Its presence on the skin, indicative of the acquisition of keratinophilous properties, is particularly dangerous. Trichosporon beigelii is an example of species that began colonisation of human tissues from the skin and its products (Warnock, Richardson 1991). It initially entered the urinary and genitourinary systems and then the respiratory system (Dynows k a 1995). Apart from Candida albicans, it is currently a frequent aetiological factor of mycoses of various human ontocoenoses (Dynowska 1996).

While isolating $S$. cerevisiae from the oral cavity, throat or the digestive system, especially in summer when large amounts of fruit are consumed, does not have to indicate initial stages of mycosis, recording isolates in other biological material raises certain suspicions (Dynowska, Hołoweńczak, Fiedorowicz 1997). The presence of yeasts in bronchoscopic material and in the large intestine shows the state of potential threat. Yeasts usually accompanied yeast-like fungi characterised by high pathogenicity: $C$. albicans, $C$. glabrata, $C$. tropicalis, $T$. beigelii. These species were most probably the direct cause of pathogenic changes while the yeasts constituted a secondary additional factor, which does not exclude the reverse situation. This remark seems 
particularly significant as a gradual decrease in immunity to infections caused by various fungi accompanying man and an increase in the expansive nature of a number of opportunistic forms, sometimes believed to be accidental contamination of clinical material or, even worse, a physiological element, have been observed (S e net, Robert 1995). Due to high enzymatic activity, yeasts that had been ingested or inhaled could begin destructive processes and paved the way for yeast-like fungi.

The danger posed by $S$. cerevisiae is mostly caused by its ability to grow and develop at the temperature of the human body, at the decreased oxidation and reduction potential that prevails in diseased tissue. It ecophysiology is within the definition of fungi potentially pathogenic to people (Richardson, Warnock 1995).

Yeasts are very common saprotrophes, and they naturally occur on fruit surfaces, flower nectaries, cracked tree bark and plant secretions rich in carbohydrates, eutrophied water reservoirs abundant in organic matter, and soil (Dy now ska 1995).

All fungi colonising the human body should be carefully monitored, especially as susceptibility to fungal infections is common and affects individuals of any age, both healthy and compromised. Since the range of factors predisposing to fungal infections is expanding, it is impossible to determine when a symbiotic commensal transforms into a parasite.

\section{CONCLUSIONS}

S. cerevisiae belongs to fungi that have increasingly been colonising various human ontocoenoses, including the skin.

The results of clinical studies in which $S$. cerevisiae occurs should be analysed in depth as its enzymatic activity and expansive behaviour in relation to human tissues is growing.

\section{REFERENCES}

Barnett J. A., Payne R. W., Yarrow D. 1990. Yeast: Characteristic and identification. Cam brige Univ. Press.

Dyn ow ska M. 1995. Drożdże i grzyby drożdżopodobne jako czynniki patogenne i bioindykatory eko systemów wodnych. Studia i Materiały WSP Olsztyn 77: 183.

Dynowska M. 1996. Trichosporon species isolated from human respiratory system. Acta Mycol. 31 (2): 137141.

Dynowska M., Biedunkiewicz A. 2001. Grzyby chorobotwórcze o wzrastającej ekspansywności. Wiad. Parazytol. 47 (4): 609613.

Dynowska M., Ejdys E., Kisicka I. 2004. Susceptibility to antifungal agents of yeast like fungi and yeast isolated from people with multilocal infections. Mikol. Lek. 11 (1): 1519.

Dynowska M., Hołoweńczak A., Fiedorowicz G. 1997. Drożdże i grzyby drożdżopodobne izolowane z wybranych owoców i nasion jako mało znane czynniki patogenne. (In:) Konferencja Naukowa Promocyjna „Lepsza Żywność” (IV). ART. Olsztyn Kortowo: 5255.

Kurnat owska A. 1995. Wybrane zagadnienia z mikologii medycznej. Wyd. II. Promedi, Łódź.

Kreger van Rij N. J. W. 1984. The yeasts: a taxonomic study. Third revision and enlarged edition. Els. Sci. Publ. Amsterdam.

Pawlik B., Macura A. B. 1998. Diagnostyka laboratoryjna w mikologii. (In:) E. Baran (ed.). Zarys mikologii lekarskiej. Volumen Wrocław: 541572.

Richardson M. D., Warnock D. W. 1995. Grzybice rozpoznanie i leczenie. Springer. PWN, Warszawa.

Senet J. M., Robert R. 1995. Physiopathologie des candidoses. J. Mycol. Med. 5: 145166.

Warnock D. W., Richardson M. D. 1991. Fungal infection in the compromised patients. Chi chester John Viley. 
Saccharomyces cerevisiae w układzie oddechowym, pokarmowym i na skórze człowieka

\section{Streszczenie}

Przeanalizowano (1999 2004) udział S. cerevisiae w dodatnich wynikach mikologicznych (2880 prób) Pracowni Bakteriologii SPZG i ChP w Olsztynie. Grzyby pochodziły z różnych odcinków ontocenozy układu oddechowego, pokarmowego oraz ze skóry pacjentów onkolo gicznych i z przewlekłymi chorobami układu oddechowego, w tym podejrzanych o gruźlicę. Ogólnie uzyskano 317 izolatów S. cerevisiae, co stanowi 11,04\% wszystkich stwierdzonych grzybów gatunek ten najczęściej towarzyszył licznym grzybom drożdżopodobnym (Candida, Trichosporon). Ontocenozą najczęściej zasiedlaną przez $S$. cerevisiae był układ pokarmowy, a następnie oddechowy. Na skórze notowano go głównie w ostatnich dwóch latach badań. O ile w układzie oddechowym i pokarmowym drożdże pojawiały się z podobną częstością u kobiet i mężczyzn (z niewielkim przesunięciem w kierunku kobiet), to na skórze kobiet notowano je prawie dwukrotnie częściej. $\mathrm{Z}$ reguły izolowano je latem i jesienią, rzadko wiosną i zimą. We wszystkich ontocenozach zauważono wyraźny wzrost prewalencji badanego gatunku, co może świadczyć o wzroście jego ekspansywności w stosunku do organizmu człowieka. 